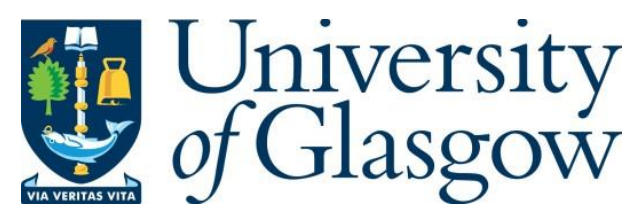

Liu, X., Falcone, G. and Alimonti, C. (2018) A systematic study of harnessing lowtemperature geothermal energy from oil and gas reservoirs. Energy, 142, pp. 346-355.

There may be differences between this version and the published version. You are advised to consult the publisher's version if you wish to cite from it.

http://eprints.gla.ac.uk/165751/

Deposited on: 27 May 2020

Enlighten - Research publications by members of the University of Glasgow http://eprints.gla.ac.uk 


\title{
A Systematic Study of Harnessing Low-Temperature Geothermal Energy from Oil and Gas Reservoirs
}

\author{
Xiaolei Liu, ${ }^{\text {a, }}$ Gioia Falcone, ${ }^{\mathrm{a}}$ and Claudio Alimonti ${ }^{\mathrm{b}}$ \\ ${ }^{\text {a }}$ Oil and Gas Engineering Centre, Cranfield University, MK43 OAL, Cranfield, UK \\ ${ }^{\mathrm{b}}$ Sapienza University of Rome, Dipartimento Ingegneria Chimica Materiali Ambiente, Piazzale Aldo Moro 5, 00185 Rome, Italy
}

\begin{abstract}
Mature hydrocarbon fields co-produce significant volumes of water. As the produced water increases over the life of the field, the project's operating costs increase (due to greater water management expenditure), while the oil revenues decrease. Typically, these waste streams of water have temperatures of 65 to $150{ }^{\circ} \mathrm{C}$. The combination of moderate temperatures and large water volumes may be suitable for electricity generation and/or district heating. Being able to capture the geothermal energy from existing hydrocarbon fields could extend their lifespan by delaying their economic cut-off point. The emissions of greenhouse gases could also be reduced by in-field generation and consumption of renewable, low carbon energy.

In this paper, mature oil and gas reservoirs worldwide are critically reviewed, where waste heat recovery has already been tested, or its potential identified. A roadmap of screening criteria based on geological, reservoir, production and economic parameters is then proposed, to assess how, where and when low-temperature waste heat recovery is feasible. The roadmap is tested against the Villafortuna-Trecate oil field in Italy, where the aquifer not only provides pressure support to the reservoir, but also represents a natural, in-situ hydrothermal resource. The results suggest that a single-well could recover approximately 25 GWhof electric power over a 10-year period, with an installed capacity of $500 \mathrm{~kW}$.
\end{abstract}

Keywords: Low-temperature geothermal resources; Geothermal co-production; Mature hydrocarbon fields

\section{Introduction}

The rapid economic growth worldwide creates a strong market demand for energy, which leads to an increased use of conventional fossil fuels and hence an adverse impact on the environment. On the other hand, the more environmentally friendly renewable energy resources still have a long way to go before they can replace fossil fuels. This transition can be facilitated by hybrid projects combining different types of energy sources. Harnessing the geothermal potential of the water co-produced in hydrocarbon developments is an example of hybridization.

Since the $20^{\text {th }}$ century, electrical power has been generated from high-temperature geothermal fluids such as steam (e.g. the Geyers in USA) or a mixture of steam and water (e.g. the Krafla in Iceland). These geothermal resources are typically mined with dry steam power plants or single/double flash power plants [1]. As the more favourable geothermal resources have been already discovered and given the natural predominance of low- to medium-temperature resources, the latter have become the focus of the geothermal sector. Thanks to modern technologies, converting low-temperature heat to electric power has become possible [2], particularly via binary power plants [3]. These use working fluids with liquid-vapor phase change in the secondary loop to allow the system to run more effectively at temperatures below the boiling point of water. Considering that many oil and gas wells around the world produce fluids at temperatures between 65 and $150{ }^{\circ} \mathrm{C}$, there is scope for applying binary power plant technology in hydrocarbon developments. Here, the reservoir, the wells and the production system are already in place, which means that significant capital expenditure has already been invested for the hydrocarbon development and does not need to be made again for the geothermal add-on. It should be noted that some authors [4-6] classify the extraction of geothermal energy from oil and gas reservoirs under the category of engineered geothermal systems (EGS).

Primarily, in hydrocarbon reservoirs, low-temperature geothermal energy could be recovered from:

\footnotetext{
${ }^{*}$ Corresponding author.

E-mail address: Xiaolei.Liu@ cranfield.ac.uk (X. Liu).
} 
1) The naturally co-produced water from hydrocarbon reservoirs

In oil and gas fields, the water co-produced with the hydrocarbons must be separated and disposed of in respect of the environment, considering that it may contain salt or heavy metals. Depending on location (onshore or offshore) and field development scheme, the treated water may be re-injected underground or discharged overboard, for example. Water treatment and disposal carry significant costs to the operators. In the petroleum industry, several oil and gas wells have achieved or are about to reach their economic. In the Texas Gulf Coast alone, thousands of wells have already been abandoned [7]. Normally, when a hydrocarbon well is abandoned, public authorities formulate enforceable regulations for environmental protection and public safety in the areas nearby, which is an addition charges for the operators. Generating green electrical power from the co-produced water can offset fuel costs and reduce operational expenditure, delaying decommissioning liabilities and increasing ultimate oil recovery.

2) Water re-circulation through previously steam-flooded heavy oil reservoirs

Limpasurat et al. [21] discussed the opportunity to harness geothermal energy from heavy oil fields that have undergone steam-flooding and so accumulated substantial heat from steam injection. Once the steam-flooding process reaches economic cut-off, due to high water cut and/or high steam-to-oil ratio, the reservoir would be abandoned, leaving behind stored energy in the form of heat. From this point, the reservoir could be regarded as an artificial geothermal system, and its intrinsic heat recovered by water circulation. Preliminary investigations showed that it could be possible to advantageously extend the life of heavy oil fields by means of a heat-recovery phase after the oil-recovery phase.

\section{Overview of low-temperature geothermal energy recovery from oil and gas fields worldwide}

Even though the concept of extracting heat from hydrocarbon production is relatively novel, a few field pilots and preliminary studies have been successfully carried out in recent years. In the following section, six case studies worldwide are critically reviewed to assess the feasibilities of harnessing heat from mature hydrocarbon fields.

\subsection{Mature Fields with Implemented Heat Extraction Projects}

Geothermal power units have already been installed at the Naval Petroleum Reserve (USA) and Huabei (China) oil fields.

\subsubsection{Naval Petroleum Reserve NO.3 (NPR-3), Wyoming, USA}

Naval Petroleum Reserve NO.3 (NPR-3), which was operated by the U.S. Department of Energy (DOE), is located at Teapot Dome field in the north of Casper. Its commercial production started in the early 1920s, after which it was shut-in for a relatively long time. In 1976, NPR-3 was fully developed at a field level. Its average reservoir temperature is around 110 ${ }^{\circ} \mathrm{C}$, with a geothermal gradient of $2.5{ }^{\circ} \mathrm{C} / 100 \mathrm{~m}$. The oil production creates large volume of co-produced hot water with temperatures of $80-90{ }^{\circ} \mathrm{C}$ from more than 700 active wells. The site has a steady and abundant water supply from the Big Horn Range which is located in the northwest of the field, with a $2438 \mathrm{~m}$ hydraulic head above the field's surface. [8]

Because of increasing operational costs and declining oil production, DOE decided to employ NPR-3 as a demonstration site for low-temperature geothermal energy recovery in 2007. In August 2008, a $250 \mathrm{~kW}$ Organic Rankine Cycle (ORC) power plant was installed to utilize the low-enthalpy energy from hot co-produced water in the field. In order to accommodate the new geothermal component, some field infrastructure was upgraded, including insulation of surface pipes to minimise heat losses and additional water storage tanks [9]. Until the beginning of 2011, the ORC unit outputted more than $1900 \mathrm{MWh}$ of power [10]. This was the first use of co-produced hot water in an operating oil field to generate electricity. In 2013, DOE recommended to US Congress that NPR-3 should be sold to the private sector, to be continuously used as a productive oil field. In 2015, the DOE finalized the sale of the Teapot Dome oilfield to a private company [11]. The historical milestones of NPR-3 are summarized in Table 1.

Table 1 Historical milestones of NPR-3.

\begin{tabular}{|l|c|}
\hline Years & Milestones \\
\hline 1920 & Production started \\
\hline 1976 & Fully developed at field level \\
\hline 2000 & Oil production declined \\
\hline 2007 & Employed as a demonstration site for geothermal energy extraction \\
\hline
\end{tabular}




\begin{tabular}{|l|c|}
\hline 2008 & $250 \mathrm{~kW}$ ORC power plant installed \\
\hline 2011 & Cumulative electrical output of over $1900 \mathrm{MWh}$ \\
\hline 2014 & Sold to a private company \\
\hline
\end{tabular}

\subsubsection{Huabei Oil Field, Hebei, China}

The Huabei oil field, which is operated by China National Petroleum Corporation (CNPC), is located in the Hebei province of northern China. It is a typical buried hill oil field with a nose-shaped peak surface. In 1970s, the field made a great contribution to the development of the Chinese petroleum industry. For around 15 years, it occupied the third place in the country for hydrocarbon production. In June 1978, the LB reservoir, which is located to the east of the Huabei field, was put on production, mainly by natural depletion. Only four month later, water injection was initiated to increase the efficiency of oil recovery. There are 27 existing wells in place and only 6 of them are production wells. After more than 30 years of water flooding, the total flow rate has declined from the original $700 \mathrm{~m}^{3} /$ day to about $150 \mathrm{~m}^{3} / \mathrm{day}$. The current reservoir temperature is about $120^{\circ} \mathrm{C}$, with a geothermal gradient of $3.5^{\circ} \mathrm{C} / 100 \mathrm{~m}$ [12]. As a result of very high water cut (> 97\%) and consequent declining hydrocarbon production, its development is almost completed [13]. In 2007, CNPC conducted a pilot test to harness geothermal energy from the LB reservoir [14].

In early April 2011, a $400 \mathrm{~kW}$ binary power generator was installed, representing the first heat-electricity unit to use low-enthalpy energy from co-produced fluids in a hydrocarbon field in China. At surface, the temperature of the geofluids is around $110{ }^{\circ} \mathrm{C}$. The total flow rate is approximately $2880 \mathrm{~m}^{3} / \mathrm{d}$, from 8 active wells. Until the end of 2011 , the effective operation time was 2880 hours and cumulative electricity generation was around $31 \times 10^{4} \mathrm{kWh}$ [12]. A summary of the historical milestones of the LB reservoir of the Huabei oilfield is shown in Table 2.

Table 2 Historical milestones of the LB reservoir of Huabei oilfield

\begin{tabular}{|l|c|}
\hline Years & State points \\
\hline 1975 & Discovered \\
\hline 1976 & Production started \\
\hline 1986 & Oil production declined \\
\hline 2007 & Employed as a pilot site for geothermal energy extraction \\
\hline Early April 2011 & 400 kW binary power plant installed \\
\hline End of 2011 & Cumulative electrical output of over 310 MWh \\
\hline
\end{tabular}

\subsubsection{Additional projects}

In addition to the above two cases, the DOE recently announced that geothermal power was successfully generated from petroleum facilities in the Williston Sedimentary Basin of western North Dakota[15].

\subsection{Oil and gas reservoirs with identified heat recovery potential}

The heat recovery potential of several giant oil and gas fields worldwide has been investigated by several studies. McKenna et al. [16] stated that over $1000 \mathrm{MW}$ of electric power could be generated from co-produced fluids in oilfields along the Gulf Coast. Limpasurat et al. [17] discussed the opportunity to harness the substantial heat accumulated in heavy oil fields that have undergone steam flooding. The authors claimed that the net power generation from a single pair of injector-producer system could be around $14 \mathrm{~kW}$. Bennett et al. [18] estimated that net geothermal power output from oilfields in the Los Angeles basin could be around $7430 \mathrm{~kW}$, with a Net Present Value (NPV) of 41 million dollars over 30 years. Sanyal et al. [19] reported that net geothermal power generation from the co-produced water in an abandoned gas well on the U.S. Gulf Coast could be $350 \mathrm{~kW}$. These studies prompt to the need for general criteria to assess the feasibility of this hybrid energy concept. Table 3 summarizes key technical data for six sets of oil and gas fields. 
Table 3 Data collection from oil and gas fields with potentials of harvesting thermal recovery.

\begin{tabular}{|c|c|c|c|c|c|c|c|}
\hline & & $\begin{array}{c}\text { NPR-3 } \\
\text { (Implemented) }\end{array}$ & $\begin{array}{c}\text { Huabei Oil } \\
\text { Field } \\
\text { (Implemented) } \\
\end{array}$ & $\begin{array}{l}\text { Oil Fields along } \\
\text { Gulf Coast } \\
\text { (Identified) } \\
\end{array}$ & $\begin{array}{c}\text { A Synthetic Heavy } \\
\text { Oil Field } \\
\text { (Identified) } \\
\end{array}$ & $\begin{array}{c}\text { Oil Fields in Los } \\
\text { Angeles } \\
\text { (Identified) } \\
\end{array}$ & $\begin{array}{c}\text { A Typical Gas Field } \\
\text { in Gulf Coast } \\
\text { (Identified) }\end{array}$ \\
\hline \multirow{5}{*}{ Oil Field } & Location & Wyoming, USA[8] & Hebei, China[13] & $\begin{array}{l}\text { Gulf Coast, } \\
\text { USA[16] }\end{array}$ & $\begin{array}{l}\text { USA, Indonesia, } \\
\text { Venezuela[17] }\end{array}$ & $\begin{array}{l}\text { California, } \\
\text { USA[20] }\end{array}$ & Gulf Coast, USA[19] \\
\hline & Hydrocarbon Type & $\operatorname{Oil}[8]$ & Oil[13] & Oil[16] & Heavy Oil[17] & Oil[20] & Gas[19] \\
\hline & Current Status & Mature[8] & Mature[12] & Operating[16] & Abandoned[17] & Operating[20] & Abandoned[19] \\
\hline & Secondary Recovery Mechanism & - & $\begin{array}{c}\text { Water } \\
\text { Flooding[12] }\end{array}$ & $\begin{array}{c}\text { Water } \\
\text { Flooding[16] }\end{array}$ & Steam Flooding[17] & $\begin{array}{l}\text { Water Flooding \& } \\
\text { Steam Flooding[20] }\end{array}$ & - \\
\hline & Water Cut & - & High[12] & $\operatorname{High}[16]$ & - & High[20] & $\operatorname{High}[19]$ \\
\hline \multirow{5}{*}{ Well } & Well Depth, m & $\sim 1524[8]$ & - & $3500-5000[16]$ & $472[17]$ & $\sim 1800-2500[18]$ & - \\
\hline & Surrounding Ambient Temperature, ${ }^{\circ} \mathrm{C}$ & $<29[10]$ & - & - & $21[17]$ & $24[20]$ & 21[19] \\
\hline & Wellhead Temperature, ${ }^{\circ} \mathrm{C}$ & 91 - 99[9] & $110-115[12]$ & $\begin{array}{c}\text { 150[16] } \\
\text { (estimated) }\end{array}$ & $93[17]$ & $80-100[18]$ & - \\
\hline & Production Rate, $\mathrm{m}^{3} / \mathrm{d}$ & 318 - 795 (per well) [8] & $\begin{array}{c}150 \text { (per well) } \\
{[13]}\end{array}$ & - & 40 (single well) [17] & - & $\sim 238[19]$ \\
\hline & Co-produced Fluids Temperature, ${ }^{\circ} \mathrm{C}$ & $\sim 88[8]$ & $110[12]$ & $\sim 150[16]$ & $72[17]$ & $>80[18]$ & $138[19]$ \\
\hline \multirow{4}{*}{ Reservoir } & Geothermal Gradient, ${ }^{\circ} \mathrm{C} / 100 \mathrm{~m}$ & $2.5^{[11]}$ & $3.5[12]$ & $\begin{array}{l}1.2-4.25[16] \\
\text { (calculated) }\end{array}$ & $4[17]$ & $3.6[20]$ & - \\
\hline & Porosity, \% & - & $6[12]$ & - & $30[17]$ & $30[18]$ & - \\
\hline & Permeability, md & - & $158[12]$ & - & $1000[17]$ & - & - \\
\hline & Reservoir Temperature, ${ }^{\circ} \mathrm{C}$ & $\sim 110[8]$ & $120[13]$ & 120 - 200[16] & $130[17]$ & $68-143[20]$ & - \\
\hline \multirow{7}{*}{ Power Plant } & Inlet Temperature, ${ }^{\circ} \mathrm{C}$ & $77[10]$ & $110[12]$ & $>150[16]$ & $72[17]$ & $80[20]$ & $138[19]$ \\
\hline & Outlet Temperature, ${ }^{\circ} \mathrm{C}$ & $8-77[10]$ & $85-90[12]$ & - & $21[17]$ & $55[20]$ & 21[19] \\
\hline & Flow Rate, $\mathrm{m}^{3} / \mathrm{d}$ & $1749-7949[10]$ & $2880[12]$ & $\begin{array}{c}>5453[16] \\
\text { (in the entire } \\
\text { region) }\end{array}$ & 40[17] (single well) & $>3715[18]$ & $1252[19]$ \\
\hline & Installed Power, kW & $250^{[7]}$ & $400[12]$ & - & - & - & - \\
\hline & Power Generation, MWh & $1918[10]$ & $310[12]$ & - & - & - & - \\
\hline & Potential Power Generation, MW & - & - & $1000-5000[16]$ & $\begin{array}{c}0.014[17] \text { (single } \\
\text { well) } \\
\end{array}$ & $7.4[20]$ & $0.35[19]$ \\
\hline & Type of Power Plant & $\begin{array}{l}\text { Binary Cycle Power } \\
\text { Plant }[10]\end{array}$ & $\begin{array}{c}\text { Binary Cycle } \\
\text { Power Plant[12] }\end{array}$ & $\begin{array}{c}\text { Binary Cycle } \\
\text { Power Plant[16] } \\
\text { (estimated) }\end{array}$ & $\begin{array}{l}\text { Binary Cycle Power } \\
\text { Plant[17] (estimated) }\end{array}$ & $\begin{array}{c}\text { Binary Cycle } \\
\text { Power Plant[20] } \\
\text { (estimated) } \\
\end{array}$ & $\begin{array}{l}\text { Binary Cycle Power } \\
\text { Plant[19] (estimated) }\end{array}$ \\
\hline
\end{tabular}


The goal of the data collection in Table 3 is to determine an acceptable range for the various parameters that makes geothermal power production from mature oil and gas fields possible, as well as to define screening criteria for suitable candidates. The key parameters are analyzed as follows:

\section{Flow rate}

The production flow rates vary considerably across the six different cases, due to the corresponding different scales. For instance, oil fields along the Gulf Coast include several fields in seven states of the U.S., while the case of the abandoned unconventional heavy oil field only describes a typical single producer. This is why the flow rate and power generation values are not of the same order of magnitude. High production flow rates are desirable for geothermal power generation from low- to medium-temperature water, as confirmed in the pilot test of Huabei oil field.

\section{Wellhead temperature}

The wellhead temperature values shown in Table 3 range from $90{ }^{\circ} \mathrm{C}$ to $110^{\circ} \mathrm{C}$. As a general criterion, it should be at least higher than the minimum temperature required for the power plant to successfully convert thermal energy into electricity. So far, the geothermal fluids at Chena Hot Springs, U.S. represent the lowest temperature of geothermal resources exploited for commercial power generation worldwide. The lowest recorded inlet temperature of the operating power plant is only $57{ }^{\circ} \mathrm{C}[21]$.

\section{Water cut}

High water cut is a universal feature of mature oil and gas fields in their late life. Most mature fields require long-term, stable water supply, such as water injection or natural fluids recharge at the reservoir boundaries to sustain hydrocarbon production. The majority of the fields analyzed here show high water cut, with the highest value being $99 \%$ for the oil fields along the Gulf Coast. Due to its high heat conductivity, water is a natural heat carrier.

\section{Average reservoir temperature and geothermal gradient}

The stored heat in subsurface systems can be estimated from the average reservoir temperature. A general conclusion is that reservoir temperature increases with depth. In Table 3, average reservoir temperatures vary from $100{ }^{\circ} \mathrm{C}$ to $200{ }^{\circ} \mathrm{C}$, suggesting that lower reservoir temperatures may not be suitable for heat recovery. The geothermal gradient is often used to represent the relationship between reservoir temperature and formation depth. For conventional reservoirs, the reservoir temperature can be calculated by multiplying the geothermal gradient by the depth of the formation. The average geothermal gradient worldwide is $1.4{ }^{\circ} \mathrm{C} / 100 \mathrm{~m}$. Its range within the six sets of oil and gas fields is between 2 and $4{ }^{\circ} \mathrm{C} / 100 \mathrm{~m}$, which is higher than the typical value.

\section{Permeability \& Porosity}

Permeability describes the ability of fluid flow to go through porous media. It partly controls how much heat can be transferred from the formation to the produced fluids by means of convection. Permeability for the six cases investigated here varies significantly because of the differences in geological background. Flow in porous media is also affected by the existence of natural fracture networks. The NPR-3 and Huabei fields, which possess their own natural fracture networks, present smooth flow channels for fluids flow underground. Porosity is the pore volume fraction of the total volume of the rock. It can be used to represent the amount of fluids in place in the reservoir. In Table 3, the lowest porosity (6\%) is shown by the LB reservoir in the Huabei field. However, considering the natural fractures that greatly enhance heat transfer by convection, the LB reservoir is still a promising candidate for low-temperature heat recovery.

\section{Water flooding and steam flooding}

Most of the fields listed in Table 3 have a long water flooding history. Water injection is one of the most popular methods for the secondary recovery phase of oil and gas fields. It can complement reservoir pressure effectively and create sizable volume of water underground at the same time. This large volume of water can become a favorable transmission medium for geothermal energy. Steam flooding is another widespread method to improve the efficiency of oil recovery. It can decrease oil viscosity, while leaving considerable waste heat subsurface. Such waste energy offers significant potentials for heat recovery. In the six cases of Table 3, two of them have a history of steam flooding.

\section{Type of Power Plant}


Almost all projects and studies used or recommended the use of ORCs for geothermal energy conversion in oil and gas fields. As previously discussed, ORCs are best suited for low- to medium-temperature applications.

In summary, the potential ability of thermal energy recovery in oil and gas reservoirs is related to a number of key parameters. Among them, flow rate and permeability can be artificially improved, e.g. by hydraulic stimulation.

\section{Roadmap to geothermal energy recovery from oil and gas reservoirs}

A roadmap of heat recovery from hydrocarbon systems can be derived from previous projects and studies. Fig. 1 shows a basic framework consisting of four main components - Surface Facilities \& Power Plant, Injector, Reservoir and Producer. In this framework, the geofluids are the heat carrier, extracting heat from the subsurface and bringing it to the wellhead. The geofluids are then further transported to the power plant to vaporize the working fluid and convert thermal energy into electricity before going to a separator. After separation, the water can be re-injected into the formation and circulated in the production system repeatedly. Note that it may be more efficient to separate the water from the hydrocarbons before the inlet to the ORC, due to the better thermal properties of the water in comparison with hydrocarbon oil and gas.

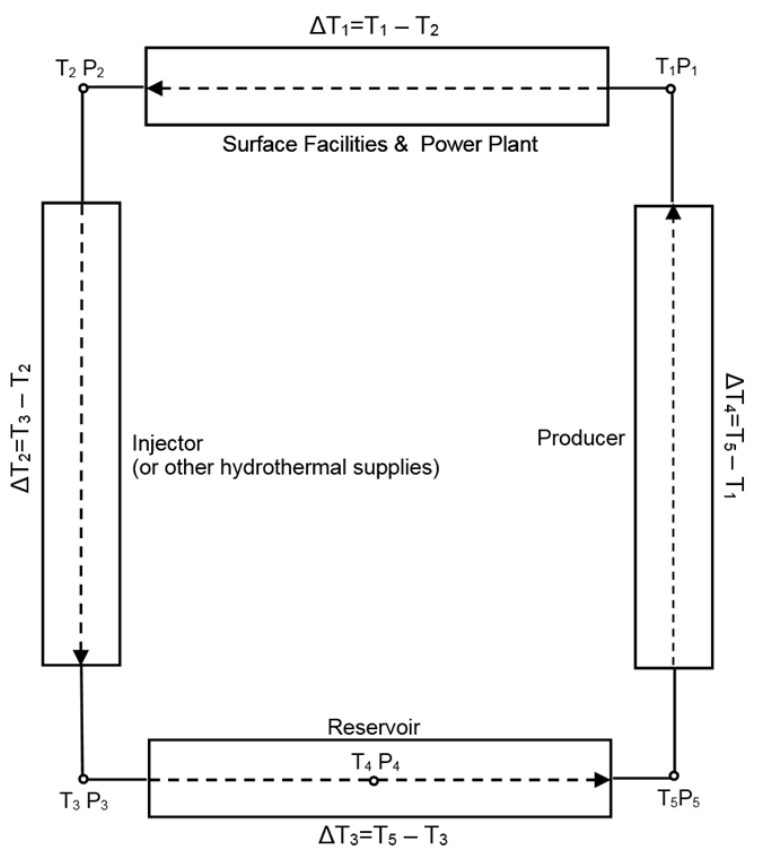

Explanation for symbols:

Temperature

$\mathrm{T}_{1}$ : Wellhead temperature of producer \& Inlet temperature of power plant (ignoring heat losses in surface pipelines).

$\mathrm{T}_{2}$ : Outlet temperature of separator \& Surface temperature of re-injected

fluids (ignoring heat losses in surface pipelines).

$\mathrm{T}_{3}$ : Re-injected temperature at the bottomhole of injector.

$\mathrm{T}_{4}$ : Average reservoir temperature.

$\mathrm{T}_{5}$ : Temperature of co-produced fluids at the bottomhole of producer.

Pressure

$\mathrm{P}_{1}$ : Wellhead pressure of producer \& Inlet pressure of power plant.

$\mathrm{P}_{2}$ : Outlet pressure of separator \& Inlet pressure of injector.

$\mathrm{P}_{4}$ : Bottomhole pressure of injector.

$\mathrm{P}_{5}$ : Average reservoir pressure.

$\mathrm{P}_{6}$ : Bottomhole pressure of producer.

Fig. 1. Simplified scheme for geothermal energy recovery from hydrocarbon systems.

Nodal analysis can be used to support the integrated structure of the roadmap, with the aim of forecasting system response (e.g. pressure and temperature at each node) to production scenarios over time. The nomenclature in Fig. 1 refers to different nodes along the system. The inlet to the power plant (downstream of the wellhead of the producer) represents the minimum required inlet temperature of the power plant and can be readily checked at surface. This point is therefore taken as the starting node for the roadmap.

\section{Node 1: Inlet to power plant and wellhead of producer}

Due to the limitation of modern energy conversion technology, the minimum required inlet temperature for the power plant is defined as $57^{\circ} \mathrm{C}$ [21]. It is assumed that the inlet temperature is equal to the wellhead temperature of the producer, so the lowest value of the wellhead temperature is also considered as $57{ }^{\circ} \mathrm{C}\left(\mathrm{T}_{1} \geq 57{ }^{\circ} \mathrm{C}\right)$. If $\mathrm{T}_{1}$ is lower than this cut-off value, the power plant cannot be operated, indicating that the current reservoir is not a suitable candidate. There are several methods to enhance wellhead temperatures, e.g. by increasing the well flow rate. The wellhead pressure $\left(\mathrm{P}_{1}\right)$ can be used to control the production rate via wellhead choke valves.

Node 2: Outlet point of separator and Inlet point of injector 
The outlet temperature from the separator is assumed to be equal to the surface temperature of the re-injected fluids $\left(\mathrm{T}_{2}\right)$. Similarly, the outlet pressure of the separator is assumed to be equal to the inlet pressure of the injector $\left(\mathrm{P}_{2}\right)$. The temperature differential between $T_{1}$ and $T_{2}\left(\Delta T_{1}\right)$ is a significant parameter for geothermal power generation. The inlet temperature of the power plant $\left(T_{1}\right)$ reflects the amount of heat captured from the subsurface. The outlet temperature $\left(T_{2}\right)$ represents the thermal energy left in the fluids after the heat exchange process in the ORC. For a given $T_{1}$, the power output increases with decreasing $\mathrm{T}_{2} . \Delta \mathrm{T}_{1}$ in relation to the geothermal power generated represents the system's effectiveness.

\section{Node 3: Bottomhole of injector}

After the co-produced fluids are separated at the separator, the disposed water is re-injected underground via the injector. In this process, the injected water is heated by the surrounding rock because of the temperature differential between water and formation. So the injected temperature $\left(T_{2}\right)$ will be lower than the temperature at bottomhole $\left(T_{3}\right)$. The heat transfer process in the injection well can be displayed through a temperature profile. The temperature differential between $T_{2}$ and $T_{3}$ $\left(\Delta \mathrm{T}_{2}\right)$ shows the increment of thermal energy of the injected fluids from surface to bottomhole. The injection pressure $\left(\mathrm{P}_{2}\right)$ should ensure that the corresponding bottomhole pressure of the injector $\left(\mathrm{P}_{3}\right)$ remains between the average reservoir pressure $\left(\mathrm{P}_{4}\right)$ and the natural facture pressure of the formation.

For water sources of a mature field, two different scenarios may happen:

- Weak natural water drive with partial water injection (such as a mature field with a long time water flooding history).

- Strong natural water drive with no water injection (such as a mature field with powerful aquifers).

It is possible that a single producer, without a paired injection well, is in communication with a strong aquifer in the field.

\section{Node 4: Reservoir}

At the bottomhole location of an injector, the injected water would sweep through the reservoir, and in doing so extract heat. One direct indicator of the stored heat underground is the average reservoir temperature $\left(T_{4}\right)$. Several factors may affect the reservoir temperature decline, such as re-injection rates, re-injected temperatures, water cut, rock conductivity and so forth. To ensure a steady power generation, the reservoir temperature should decrease with a suitable gradient through its lifetime, which can be controlled by injection scheduling. Reservoir pressure $\left(\mathrm{P}_{4}\right)$ is a function of production time and the reservoir volume produced vs. the voidage replaced by water injection.

\section{Node 5: Bottomhole of producer}

The pressure drop between the average reservoir pressure $\left(\mathrm{P}_{4}\right)$ and the bottomhole pressure of producer $\left(\mathrm{P}_{5}\right)$ forces subsurface fluids flow to the wellbore. The maximum flow rate can be assessed through Darcy's law to identify the deliverability of the reservoir. The temperature differential between $T_{3}$ and $T_{5}\left(\Delta T_{3}\right)$ shows the thermal energy that the heat carrier harvests from the subsurface. If the production bottomhole pressure $\left(\mathrm{P}_{5}\right)$ is not sufficient to transmit fluids to the wellhead, artificial lift needs to be installed in the producer.

Knowing temperatures of co-produced fluids at the bottomhole of producer $\left(\mathrm{T}_{5}\right)$ and the corresponding flow rates in the production well, wellhead temperatures $\left(\mathrm{T}_{1}\right)$ can be calculated. This heat transfer process can be displayed in a temperature profile along the producer. The temperature differential between $\mathrm{T}_{5}$ and $\mathrm{T}_{1}\left(\Delta \mathrm{T}_{4}\right)$ shows heat losses in the production wellbore. When the wellbore is very deep, the value of $\Delta \mathrm{T}_{4}$ could be relatively large.

\section{Case Study - the Villafortuna-Trecate oil field in Italy}

The case study of this section presents a detailed assessment of the potential for generating geothermal energy from coproduced fluids of a single-well in the Villafortuna-Trecate oil field, Italy. The field has a strong aquifer that not only provides pressure support, but also signifies an in-situ hydrothermal resource, without the existence of artificial water recirculation. Based on the roadmap described in Section 3, an integrated study was performed to simulate fluids flow from the reservoir to surface, via a single-well system, and then through an ORC power plant.

\subsection{The target field}


The Villafortuna-Trecate oil field consists of a naturally fractured carbonate reservoir, with high pressure and high temperature (HPHT), under the operation of ENI-Agip. It was discovered in the western Po Valley in 1984. The reservoir depth is around $5000 \mathrm{~m}$ and the original oil in place (OOIP) was about 300 million barrels [22]. In 1989, the field was formally brought onto production at a flow rate of $82,000 \mathrm{bbl} / \mathrm{d}$. By the end of 2000 , it had produced $1.88 \times 10^{5}$ barrels of oil and 70 billion cubic feet of gas [23]. This mature field is now in decline and its petroleum production is continuously reducing [24]. The target reservoir is linked to a sizable aquifer, where constant reservoir temperature and pressure can be maintained. When fluids were produced from the reservoir, water and heat would be replaced by the encroaching aquifer. The reservoir temperature is greater than $160^{\circ} \mathrm{C}$ at a depth of greater than $5500 \mathrm{~m}$ [25], which represents a substantial in situ thermal energy. The porosity of the reservoir is relatively low, at only 3-5\%, but the existing naturally fractured networks provide a high permeability of $600 \mathrm{md}$ [26]. In this field, some wells are still producing undersaturated oil together with water, which means these wells' wellhead pressures are above the corresponding bubble point pressures. The co-produced fluids' temperature is about $110^{\circ} \mathrm{C}$ and the flow rate is around $8000 \mathrm{~m}^{3} / \mathrm{d}$ at the wellhead. These recorded flow rates and temperatures fit the lowest constraint of ORC power plants, and therefore offer the possibility of installing heat-electricity units (refer to Node 1 in Fig. 1).

\subsection{Reservoir modeling}

A 1-D reservoir model was developed to analyze a single producer in the Villafortuna-Trecate field using the numerical reservoir simulator TOUGH2 [27]. In the simulation, it is assumed that the single production well is positioned in the center of a circular reservoir (Fig. 2). The zone between the wellbore and the boundary (aquifer) was split into 52 grids, where the first grid was set to have a minor radius to characterize the borehole. The thickness of reservoir was defined to be uniform, so the model geometry consisted of 52 concentric cylinders of the same height. Fluid flow was restrained in the radial direction. The well block was defined as $100 \mathrm{~m}$, and the grid was then enlarged to a radius of $600 \mathrm{~m}$, which is equivalent to the drainage area of the well. The external boundary condition of the reservoir was set as an infinite acting aquifer; such a boundary is realized by an "inactive" grid block (refer to Node 3 in Fig. 1). Under such a boundary condition, there is no pressure drop or temperature change at the outermost block while the well is on production.

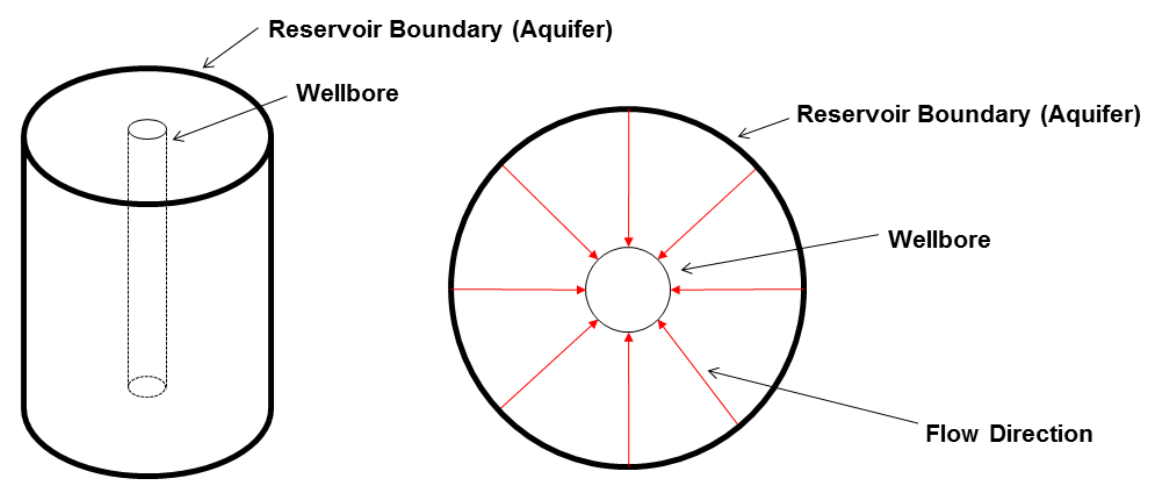

\section{Radial-cylindrical flow reservoir model of a single producer (Left: front view; Right: top view)}

Fig. 2. The geometry of the built reservoir model (after [28]).

In the model, oil recovery is defined as an isothermal process, where the reservoir temperature stays as a constant of $168^{\circ} \mathrm{C}$ (refer to Node 4 in Fig. 1). As stated, the field contains undersaturated oil due to the high reservoir pressure. Therefore, only water and oil were considered in the simulation. As gas is not present and the compressibility of oil is very limited, the corresponding oil properties were assumed to be nearly constant with a very low oil viscosity, due to the high reservoir temperature. In the simulation, specific enthalpy, density and viscosity of the oil were expressed as functions of temperature and pressure through low-order polynomials. 
The simulated reservoir was located at a depth of $5568 \mathrm{~m}$. The formation properties were extracted from data available in the public domain regarding conventional carbonate reservoirs [29]. The field was considered to be homogeneous and isotropic. The relative permeability curves, which are presented in Fig. 3, were applied in the model.

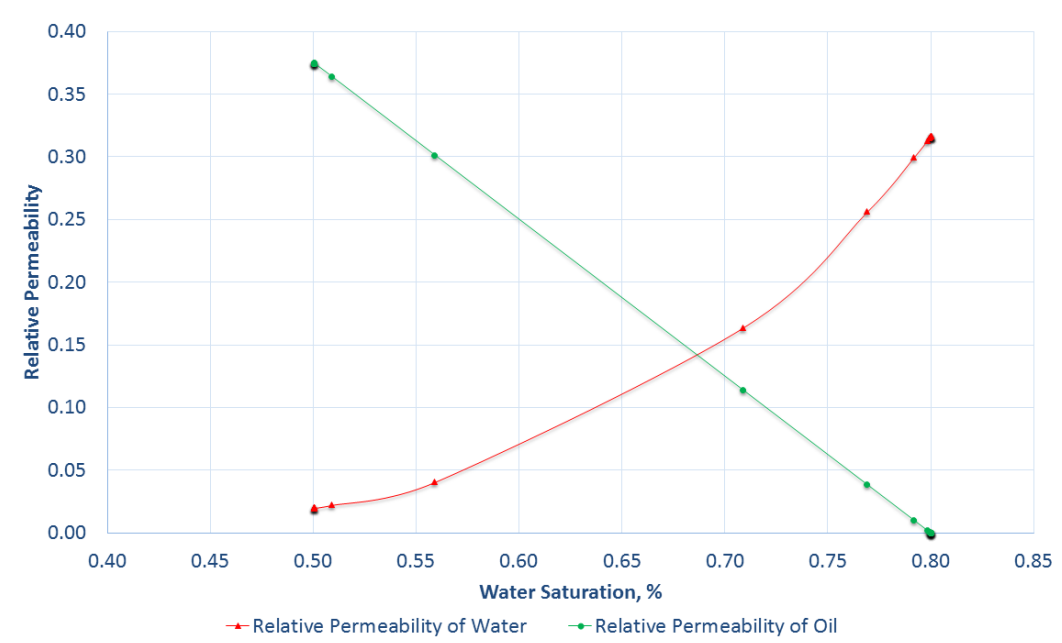

Fig. 3. Relative permeability curves used in the reservoir model.

In the homogeneous-equivalent reservoir model, some parameters (e.g., permeability) had to be calibrated to better match the actual field data. The other missing parameters were calculated from existing data to warranty the internal consistency of the simulation inputs. All the input parameters used during the modelling efforts are summarized in Table 4.

Table 4 Parameters for the reservoir modelling.

\begin{tabular}{|l|c|c|}
\hline Parameter & Unit & Value \\
\hline Rock grain density & $\mathrm{kg} / \mathrm{m}^{3}$ & 2600 \\
\hline Rock gain heat conductivity & $\mathrm{W} / \mathrm{m}^{\circ} \mathrm{C}$ & 2 \\
\hline Rock grain specific heat capacity & $\mathrm{J} / \mathrm{kg}{ }^{\circ} \mathrm{C}$ & 1000 \\
\hline Constant oil viscosity (reservoir condition) & $\mathrm{Pa} \cdot \mathrm{s}$ & $0.5 \times 10^{-3}$ \\
\hline Constant oil density (reservoir condition) & $\mathrm{kg} / \mathrm{m}^{3}$ & 810 \\
\hline Specific heat capacity of oil phase & $\mathrm{J} /\left(\mathrm{kg} \cdot{ }^{\circ} \mathrm{C}\right)$ & 1000 \\
\hline Average porosity & $\%$ & 5 \\
\hline Average permeability & $\mathrm{md}$ & 25 \\
\hline Initial water saturation & $\%$ & 50 \\
\hline Initial oil saturation & $\%$ & 50 \\
\hline Residual oil saturation & $\%$ & 20 \\
\hline Irreducible water saturation & $\%$ & 20 \\
\hline Pay thickness & $\mathrm{m}$ & 30 \\
\hline Drainage radius & $\mathrm{m}$ & 600 \\
\hline Well block radius & $\mathrm{m}$ & 100 \\
\hline Initial reservoir pressure & $\mathrm{Pa}$ & $9 \times 10^{7}$ \\
\hline Initial reservoir temperature & ${ }^{\circ} \mathrm{C}$ & 168 \\
\hline Fixed flowing bottomhole pressure & $\mathrm{Pa}$ & $8.663 \times 10^{7}$ \\
\hline Productivity index & $\mathrm{m}^{3} / \mathrm{s} / \mathrm{Pa}$ & $1.7 \times 10^{-9}$ \\
\hline
\end{tabular}

In the model, the water phase moves from the aquifer into the reservoir in response to the pressure drop between the acting boundary and the fixed bottomhole pressure. As shown in Fig. 4, during the first 10 years of the simulation, the total flow rates at the wellhead surge from $2663 \mathrm{bbl} / \mathrm{d}$ to $6250 \mathrm{bbl} / \mathrm{d}$, and the water cut of the target producer rises to almost $100 \%$. In addition, oil production keeps decreasing during the entire simulation time; the cumulative oil production from this single producer is around $3.2 \times 10^{6}$ bbls. It is considered that the economic cut off time of the waste heat extraction project takes 
place when oil production has declined drastically. Therefore, the simulation time is scheduled for 10 years to sustain geothermal energy extraction and oil production in unison.

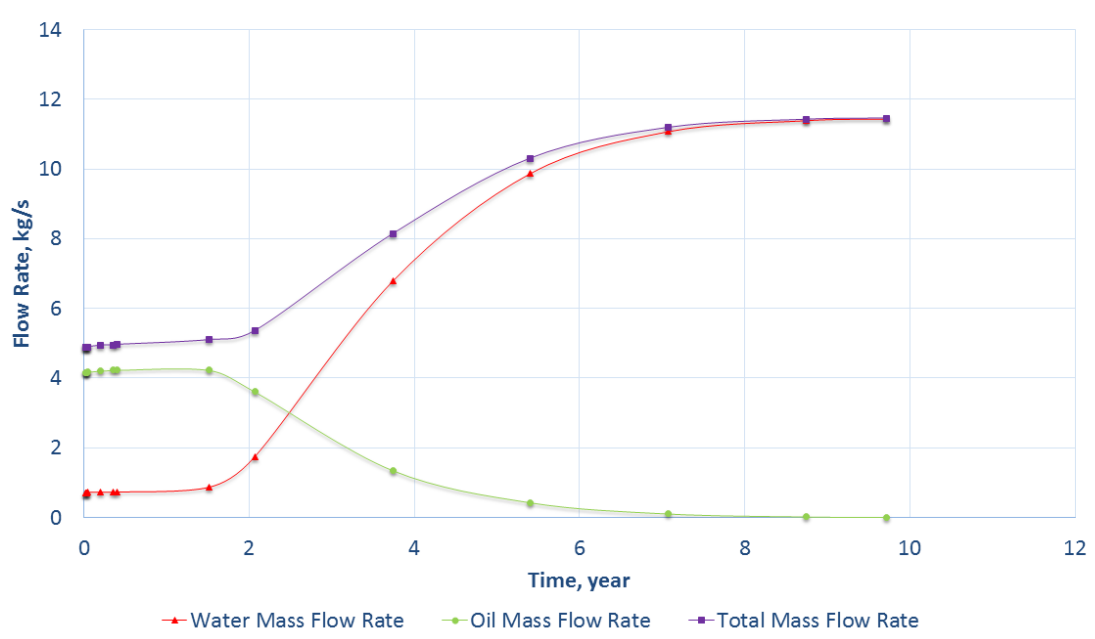

Fig. 4. Water and oil flow rates over the simulation time.

As presented in Fig. 5, the water phase made the primary contribution to thermal energy harvest compared to the oil phase because of the major heat capacity differential between the oil and water phases. In spite of the proportion of coproduced oil and water flows varying over time, the total produced heat flow keeps growing until all recoverable oil is extracted.

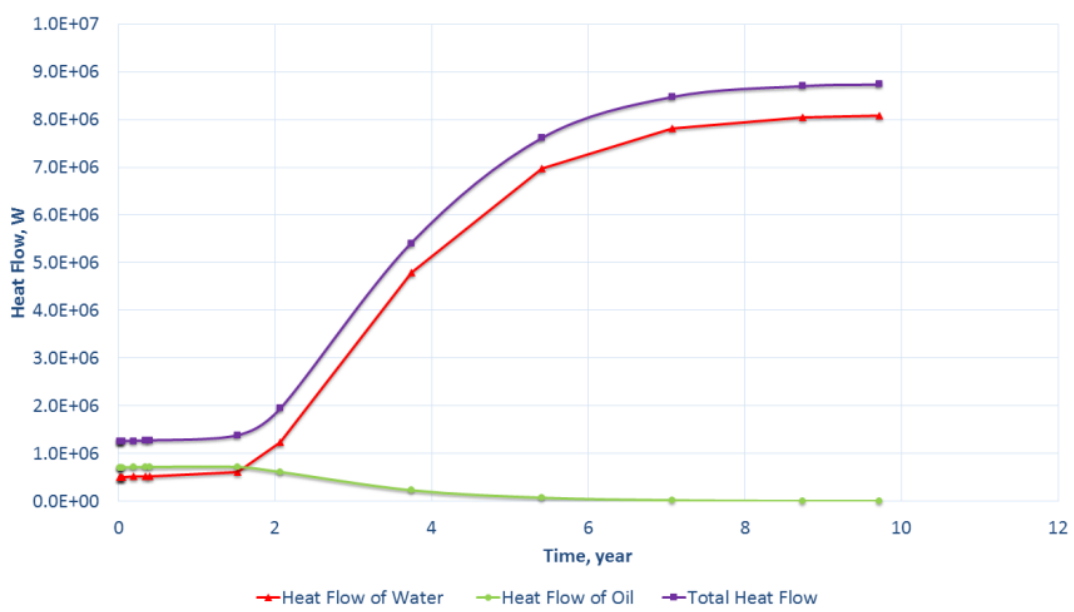

Fig. 5. Heat flow over the simulation time.

\subsection{Wellbore modelling}

The temperature profile of the co-produced fluids along the wellbore depends on their composition, the thermal properties of the surrounding rock, wellbore configuration, flow rate and time. In this paper, the steady-state equations proposed by Hasan and Kabir [30] were used to determine the temperature profiles along the target producer and calculate wellhead temperatures under the changing flow rates over the simulation time. The applied equations are as follows:

$$
T_{f}=T_{e i b h}-g_{G} \sin \alpha\left[(L-z)-\left(1-e^{(z-L) L_{R}}\right) / L_{R}\right]
$$

where: 


$$
\begin{aligned}
L_{R} & =\frac{2 \pi}{c_{p}^{\prime} W}\left[\frac{r_{t o} U_{t o} k_{e}}{k_{e}+\left(r_{t o} U_{t o} T_{D}\right)}\right] \\
T_{D} & =0.4063+\frac{1}{2} \ln t_{D} \\
\mathrm{t}_{\mathrm{D}} & =\mathrm{k}_{\mathrm{e}} \mathrm{t} / \rho_{\mathrm{e}} \mathrm{c}_{\mathrm{e}} \mathrm{r}_{\mathrm{wb}}{ }^{2}
\end{aligned}
$$

The corresponding parameters required for the computation of the above equations are presented in Table 5.

Table 5 Parameters for wellbore temperature calculations.

\begin{tabular}{|l|c|c|}
\hline Parameter & Unit & Value \\
\hline Static reservoir temperature $\left(T_{\text {eibh }}\right)$ & ${ }^{\circ} \mathrm{C}$ & 168 \\
\hline Geothermal gradient $\left(g_{G}\right)$ & ${ }^{\circ} \mathrm{C} / 100 \mathrm{~m}$ & 2.4 \\
\hline Wellbore inclination from horizontal $(\alpha)$ & ${ }^{\circ}$ & 90 \\
\hline Total measured well depth $(L)$ & $\mathrm{M}$ & 6100 \\
\hline Variable well depth from surface $(z)$ & $\mathrm{M}$ & $0-6100$ \\
\hline Co-produced fluids heat capacity $\left(c_{p}^{\prime}\right)$ & $\mathrm{Btu} /\left(\mathrm{lbm}-{ }^{\circ} \mathrm{F}\right)$ & 1 \\
\hline Mass flow rate $(\mathrm{W})$ & $\mathrm{lbm} / \mathrm{hr}$ & $46394-82135$ \\
\hline Outer radius of tubing $\left(\mathrm{r}_{\mathrm{to}}\right)$ & $\mathrm{In}$ & 1.75 \\
\hline Overall-heat-transfer coefficient $\left(\mathrm{U}_{\mathrm{to}}\right)$ & $\mathrm{Btu} /\left({ }^{\circ} \mathrm{F}-\mathrm{hr}-\mathrm{ft}^{2}\right)$ & 8 \\
\hline Thermal conductivity of formation rocks $\left(\mathrm{k}_{\mathrm{e}}\right)$ & $\mathrm{Btu} /\left({ }^{\circ} \mathrm{F}-\mathrm{day}-\mathrm{ft}\right)$ & 66.2 \\
\hline Production time $(\mathrm{t})$ & $\mathrm{day}$ & $0-3650$ \\
\hline Formation density $\left(\rho_{\mathrm{e}}\right)$ & $\mathrm{lbm} / \mathrm{ft}^{3}$ & 137.1 \\
\hline Formation heat capacity $\left(\mathrm{c}_{\mathrm{e}}\right)$ & $\mathrm{Btu} /\left(\mathrm{lbm}-{ }^{\circ} \mathrm{F}\right)$ & 0.2 \\
\hline Radius of wellbore $\left(\mathrm{r}_{\mathrm{wb}}\right)$ & in & 3.875 \\
\hline
\end{tabular}

The temperature profile along the target production well in the second year of simulation time is shown in Fig. 6. Due to the extreme depth of the well $(6100 \mathrm{~m})$, temperature losses of co-produced oil and water are higher than $40^{\circ} \mathrm{C}$ (refer to Node 1 and 5 in Fig. 1).

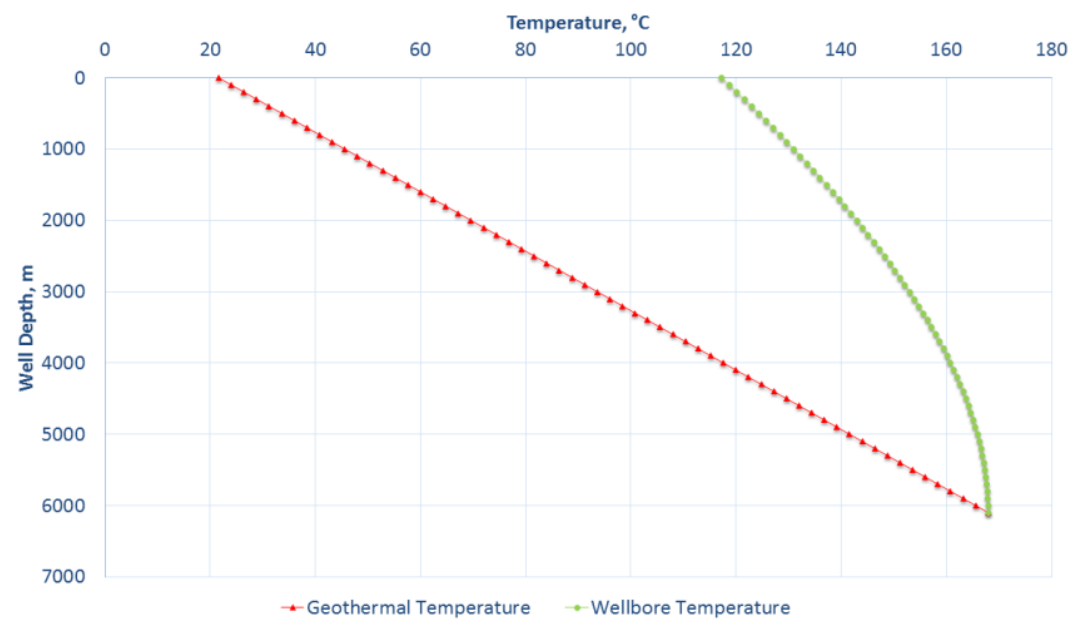

Fig. 6. Geothermal temperature vs. wellbore temperature at the second year of the simulation time.

Based on the steady-state equations suggested by Hasan and Kabir [30], the wellhead temperature is a function of flow rate, bottomhole temperature and time. As stated above, the bottomhole temperature of the producer is a constant value. On the other hand, as the aquifer is acting as an in-situ heat resource, the reservoir temperature's declining over time is relatively minor. In other words, the influence of time on wellhead temperature is also relatively small. Thus, the major impact factor on wellhead temperature is due to flow rate. Reservoir simulation results showed that the total flow rate of co-produced fluids 
rises initially, and then becomes flat (see Fig. 4). Correspondingly, the relationship between wellhead temperature and time has a similar trend, where wellhead temperature increases from $100^{\circ} \mathrm{C}$ to $139^{\circ} \mathrm{C}$ over the simulation time of 10 years.

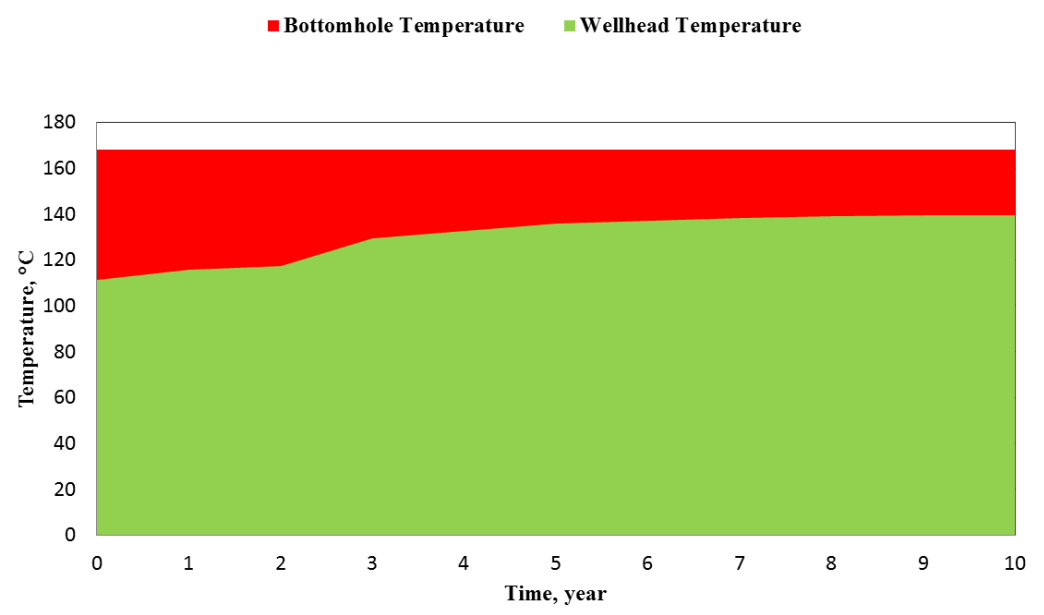

Fig. 7. Bottomhole and wellhead temperature vs. simulation time.

\subsection{Energy conversion}

In the Villafortuna-Trecate field, the deposition of wax and scale and the corrosive co-produced fluids (containing $\mathrm{CO}_{2}$ and $\mathrm{H}_{2} \mathrm{~S}$ ) had a major impact on flow assurance during oil production [26]. Accordingly, the ORC power plant was chosen as the most suitable energy generating system, where the turbine would not be in contact with the geofluids directly. Note that the reservoir pressure is considered to be sufficient to uphold the flow of co-produced fluids (oil and water) from the reservoir to the borehole (without the requirement for artificial lift) and into the power conversion unit. To evaluate the performance of the planned heat-electricity power plant, thermal efficiency is examined using a method proposed by the Massachusetts Institute of Technology [5]. A database is established according to performance statistics from fourteen ORC power plants in six different countries to determine a correlation between thermal efficiency and inlet geofluid temperatures, which are plotted in Fig. 8. Note that, in this correlation, the thermal efficiency is a function of inlet geothermal temperatures alone.

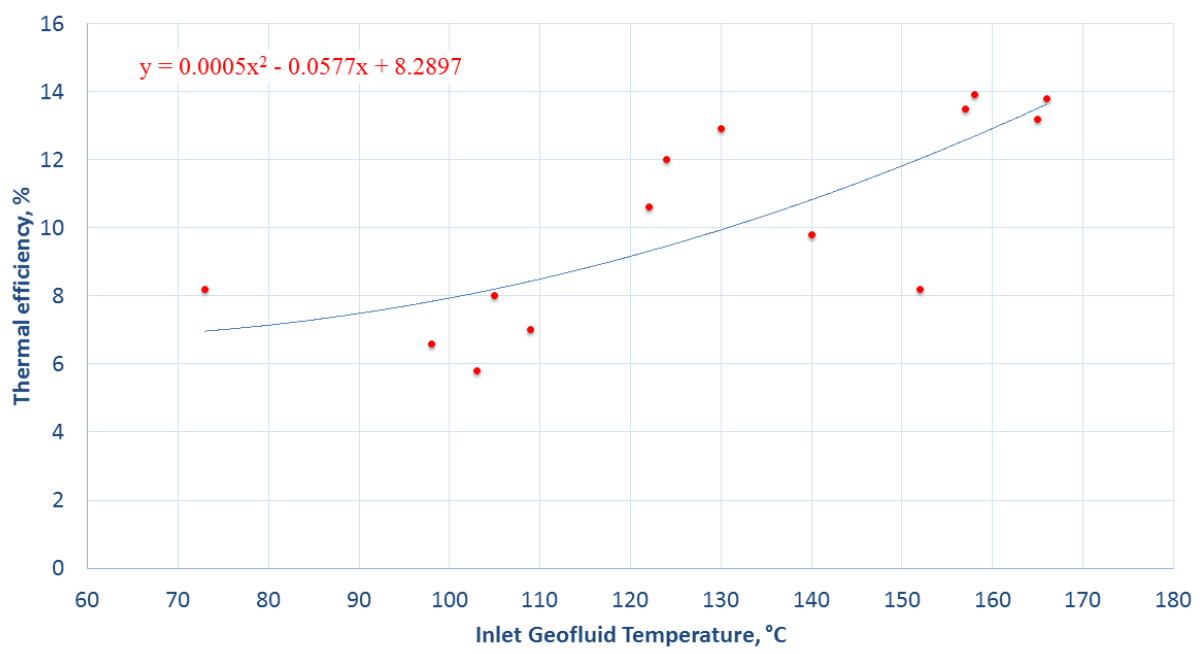

Fig. 8. Relationship between thermal efficiency and inlet geofluid temperature.

The regression correlation between thermal efficiency and inlet geofluid temperatures of ORC power plants can be expressed as: 


$$
\eta=0.0005 T_{i}^{2}-0.0577 T_{i}+8.2897
$$

Where: $\eta$ - Thermal efficiency of ORC power plant, \%

$T_{i}$ - Inlet temperature of thermal fluids, ${ }^{\circ} \mathrm{C}$

$T_{o}$ - Outlet temperature of thermal fluids, ${ }^{\circ} \mathrm{C}$

Next, the electric power output of the selected ORC power plant is:

$$
Q=c_{P} m\left(T_{i}-T_{o}\right) \eta
$$

Where: $Q$ - The electric power of the power plant, $\mathrm{kW}$

$c_{P}$ - Specific heat of geothermal fluids, $\mathrm{J} /\left(\mathrm{kg} \cdot{ }^{\circ} \mathrm{C}\right)$

$m$ - Mass flow rate, $\mathrm{kg} / \mathrm{s}$

As the power generation potential is relatively low from a single producer, a micro ORC power plant with an installed power of $500 \mathrm{~kW}$ is considered. To avoid heat losses over long distance transportation, the installed geothermal power plant needs to be located adjacent to the production well. As soluble gas phase with a low heat capacity can be discharged from the oil phase downstream of wellhead choke valve, it is presumed that the energy conversion system will be located before the choke. The parameters used in the ORC power plant design are presented in Table 6.

Table 6 Parameters for the power plant design.

\begin{tabular}{|l|c|c|}
\hline Parameter & Unit & Value \\
\hline Installed power & $\mathrm{kW}$ & 500 \\
\hline Mass flow rate & $\mathrm{kg} / \mathrm{s}$ & $4.9-11.5$ \\
\hline Inlet temperature & ${ }^{\circ} \mathrm{C}$ & $100-139$ \\
\hline Outlet temperature & ${ }^{\circ} \mathrm{C}$ & 21 \\
\hline Output power & $\mathrm{kW}$ & $49-489$ \\
\hline Thermal efficiency of power plant & $\%$ & 8.6 \\
\hline Number of power plants & - & 1 \\
\hline Type of power plant & - & ORC \\
\hline
\end{tabular}

The electric output from the co-produced fluids over the simulation time is displayed in Fig. 9 (refer to Node 2 in Fig. 1). The water phase plays a much more important role in energy conversion compared to the oil phase, as it has the ability to rapidly catch substantial amounts of heat.

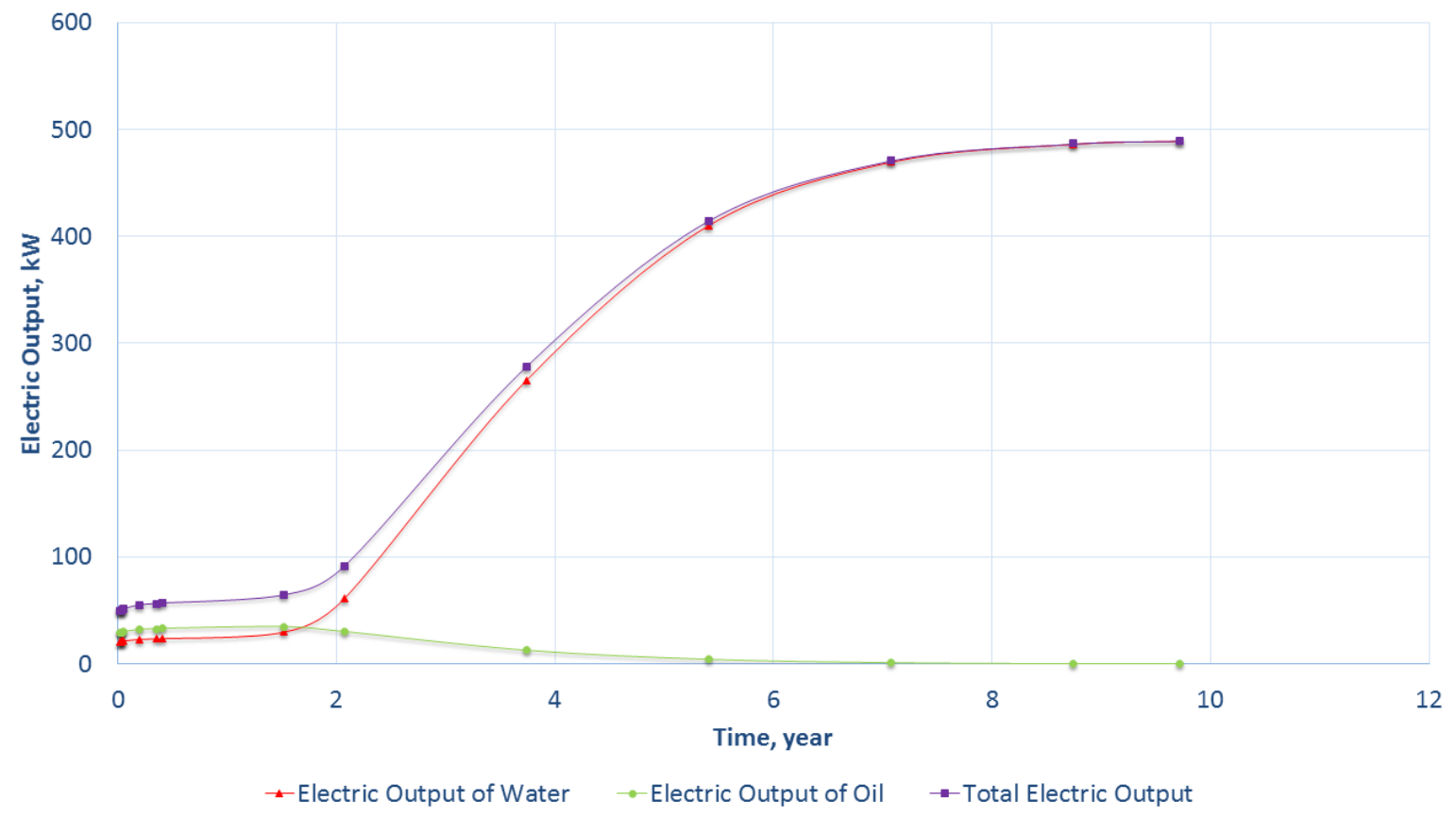


Fig. 9. Electric output over the simulation time.

\subsection{Economic assessment}

A cost-benefit assessment was performed to evaluate the economic feasibility of heat recovery in the VillafortunaTrecate oil field. In this study, the generated electric output is considered to be used to power production equipment for field operations, which balances the demand of purchasing electricity from the local grid, decreasing fossil energy consumption and so cutting pollution. Economic considerations of heat mining components are considered to be entirely self-governing and independent of the primary oil production. Compared with conventional geothermal projects, the in-place infrastructure of the field has already removed the need for most of the expenditure required for drilling and fluid collection systems. In addition, the relevant geological data are relatively detailed, being recorded after years of field production, and cutting the cost of exploration and appraisal. Subsequently, only the capital cost of the ORC power plant installation and the cost of operations and maintenance $(\mathrm{O} \& \mathrm{M})$ are deliberated in the cost-benefit assessment.

The average capital cost of a binary power plant is around $2303 € / \mathrm{kW}$ based on the Geothermal Energy Association [31]. However, the O\&M costs of binary power plants partially depend on the properties of the geofluids and the relevant legal regulations. The World Bank Group reported that O\&M costs of $200 \mathrm{~kW}$ and $20 \mathrm{MW}$ binary power plants varied in the range of $0.016-0.032 € / \mathrm{kWh}[32]$. Considering that smaller size ORC power plants have relatively higher O\&M costs than the larger ones, the O\&M costs of the ORC power plant with an installed power of $500 \mathrm{~kW}$ are assumed to be $0.03 € / \mathrm{kWh}$ in this study. In addition, the downtime of the ORC power plant is set to $10 \%$ and tax is ignored in the cash flow calculation. The Italian industrial electricity price [33] is used for the revenue calculation. Discount rates of 5\% and 10\% are considered for the calculation of NPV. All parameters used in the economic analysis are listed in Table 7.

Table 7 Parameters for the economic analysis.

\begin{tabular}{|l|c|c|}
\hline Parameters & Unit & Value \\
\hline Installed Power & $\mathrm{kW}$ & 500 \\
\hline Capital Cost & $€$ & $1.15 \times 10^{6}$ \\
\hline O\&M Cost & $€$ & $5.84 \times 10^{5}$ \\
\hline Downtime & $\%$ & 10 \\
\hline Discount Rate & $\%$ & 5 \\
\hline Total Generated Electrical Energy & $\mathrm{GWh}$ & 25 \\
\hline Electricity Price & $€ / \mathrm{kWh}$ & 0.14438 \\
\hline Lifetime & year & 10 \\
\hline NPV 5\% & $€$ & $9.57 \times 10^{5}$ \\
\hline NPV 10\% & $€$ & $4.31 \times 10^{5}$ \\
\hline
\end{tabular}

The economic analysis results show that a single production well in the Villafortuna-Trecate oil field has the capacity to produce $25 \mathrm{GWh}$ of electric power, creating an NPV of $€ 0.43$ to 0.96 million over 10 years.

\section{Conclusions}

A comprehensive review of low-temperature geothermal power generations in oil and gas reservoirs was presented, covering the major screening criteria of flow rate, wellhead temperature, water cut, reservoir temperature, temperature gradient, permeability, porosity and second recovery mechanism (water and steam flooding). The goal of the review was to identify suitable candidates for low-temperature geothermal power production among mature oil and gas reservoirs. Consequently, a roadmap for heat recovery from hydrocarbon developments was designed with the consideration of nodal analysis. In the proposed roadmap, the geofluids are naturally supplied from the aquifers or via injection wells to carry lowtemperature waste heat from reservoir to surface by production wells. Next, the produced fluids are sent into a heat-electricity unit to convert the waste heat into electricity. After the heat extraction, the separated water can be re-injected back into the reservoir and circulated between the injector-producer system repeatedly. The proposed roadmap is of general validity for the identification of candidate hydrocarbon fields for geothermal energy recovery.

The roadmap was employed to evaluate the HPHT Villafortuna-Trecate oil field in northern Italy. The positive results indicate that heat recovery is feasible and economic in this mature oilfield. The outcomes suggest that a single-well could 
generate around $25 \mathrm{GWh}$ of electric power from co-produced hot fluids along with an NPV of $€ 4.31 \times 10^{5}$ to $9.57 \times 10^{5}$ over a 10 year period.

\section{References}

[1] Ronald DiPippo. Geothermal Power Plant. Third Edit. Elsevier; 2013.

[2] Kharseh M, Al-Khawaja M, Hassani F. Utilization of oil wells for electricity generation: Performance and economics. Energy 2015;90:910-6. doi:10.1016/j.energy.2015.07.116.

[3] Zhu J, Hu K, Zhang W, Lu X. A study on generating a map for selection of optimum power generation cycles used for Enhanced Geothermal Systems. Energy 2017;133:502-12. doi:10.1016/j.energy.2017.05.130.

[4] Mohan AR, Turaga U, Shembekar V, Elsworth D, Pisupati S V. Utilization of carbon dioxide from coal-based power plants as a heat transfer fluid for electricity generation in enhanced geothermal systems (EGS). Energy 2013;57:50512. doi:10.1016/j.energy.2013.05.047.

[5] Tester JW, Anderson BJ, Batchelor AS, Blackwell DD, DiPippo R, Drake EM, et al. The Future of Geothermal Energy - Impact of Enhanced Geothermal Systems (EGS) on the United States in the 21st Century. 2006.

[6] Breede K, Dzebisashvili K, Liu X, Falcone G. A systematic review of enhanced (or engineered) geothermal systems: past, present and future. Geotherm Energy 2013;1:4. doi:10.1186/2195-9706-1-4.

[7] Nicot JP. A survey of oil and gas wells in the Texas Gulf Coast, USA, and implications for geological sequestration of CO2. Environ Geol 2009;57:1625-38. doi:10.1007/s00254-008-1444-4.

[8] Milliken M. Geothermal Resources At Naval Petroleum Reserve-3 (NPR-3), Wyoming. Thirty-Second Work. Geotherm. Reserv. Eng., Stanford, California: 2007.

[9] Johnson LA, Walker ED. Ormat : Low-Temperature Geothermal Power Generation. 2010.

[10] Reinhardt T, Johnson LA, Popovich N, Poplar N. Systems for Electrical Power From Coproduced and Low Temperature Geothermal Resources. Thirty-Sixth Work. Geotherm. Reserv. Eng., Stanford, California: 2011.

[11] Department of Energy (US). Energy Department Sells Historic Teapot Dome Oilfield 2015. http://energy.gov/articles/energy-department-sells-historic-teapot-dome-oilfield (accessed September 5, 2017).

[12] Gong B, Liang H, Xin S, Li K. Effect of Water Injection on Reservoir Temperature during Power Generation in Oil Fields. Proc. Thirty-Sixth Work. Geotherm. Reserv. Eng. 2011, Stanford, California: 2011.

[13] Xin S, Liang H, Hu B, Li K. Electrical Power Generation from Low Temperature Co-Produced Geothermal Resources at Huabei Oilfield. Thirty-Seventh Work. Geotherm. Reserv. Eng., Stanford, California: 2012.

[14] CNPC. Renewable Energy 2017. http://www.cnpc.com.cn/en/renewable/common_index.shtml (accessed September 5, 2017).

[15] Department of Energy (US). EERE Success Story—DOE-Funded Project is First Permanent Facility to Co-produce Electricity from Geothermal Resources at an Oil and Gas Well 2016. https://energy.gov/eere/success-

stories/articles/eere-success-story-doe-funded-project-first-permanent-facility-co (accessed September 5, 2017).

[16] McKenna JR, Blackwell DD, Moyes CP, Patterson PD. Geothermal Electric Power Supply Possible from Gulf Coast, Midcontinent Oil Field Waters. Oil Gas J 2005;5:34-40.

[17] Limpasurat A. Falcone G. Teodoriu C. Barrufet M. A. Artificial geothermal energy potential of steam-flooded heavy oil reservoirs. Int J Oil, Gas Coal Technol 2010;4:31-46. doi:http://dx.doi.org/10.1504/IJOGCT.2011.037743.

[18] Bennett K. Power Generation Potential from Coproduced Fluids in the Los Angeles Basin 2012:1-97.

[19] Sanyal SK, Butler SJ. Geothermal Power Capacity from Petroleum Wells - Some Case Histories of Assessment. World Geotherm Congr 2010:25-9.

[20] Bennett KP, Li K, Horne RN. Power Generation Potential from Coproduced Fluids in the Los Angeles Basin. ThirtySeventh Work. Geotherm. Reserv. Eng., Stanford, California: 2012.

[21] Erkan K, Holdmann G, Benoit W, Blackwell D. Understanding the Chena Hot Springs, Alaska, geothermal system using temperature and pressure data from exploration boreholes. Geothermics 2008;37:565-85. doi:10.1016/j.geothermics.2008.09.001.

[22] Bello M, Fantoni R. Deep oil plays in Po Valley: Deformation and hydrocarbon generation in a deformed foreland. AAPG Hedb. Conf., Sicily, Italy: 2002.

[23] Povalley Energy. Building the platform for revenue and growth. 2007.

[24] Brighenti G, Macini P, Mesini E. Sustainable management of hydrocarbon reservoirs in Italy. Tenth Congr. Int. Assoc. Eng. Geol. Environ., 2006.

[25] Galoppini M, Tambini M. Asphaltene Deposition Monitoring and Removal Treatments: An Experience in Ultra Deep Wells. Proc. Eur. Prod. Oper. Conf. Exhib., Aberdeen, UK: 1994, p. 253-62. doi:10.2523/27622-MS.

[26] Botto G, Ghetto G. Using Downhole Pressure Gauges in Hostile Deep Wells, Villafortuna-Trecate Field. J Pet Technol 1994;46:594-8. doi:10.2118/26448-PA.

[27] Pruess K, Oldenburg C, Moridis G. TOUGH2 User's Guide (Version 2). California, USA: 2011.

[28] Liu X, Falcone G, Alimonti C. Harnessing the Heat from a Mature Oil Field. Eur. Geotherm. Congr., Pisa, Italy: 2013. 
[29] Robertson EC. United States Department Of The Interior Geological Survey - Thermal Properties of Rocks. 1988.

[30] Hasan AR, Kabir CS. Fluid Flow and Heat Transfer in Wellbores. Society of Petroleum Engineer; 2002.

[31] Fleischmann DJ. An Assessment of Geothermal Resource Development Needs in the Western United States. 2007.

[32] ESMAP. Technical and Economic Assessment of Off-grid, Mini-grid and Grid Electrification Technologies. 2007.

[33] Europe's Energy Portal. Energy Prices Report (Italy). 2017. 